ҚАЗАҚСТАН РЕСПУБЛИКАСЫ

ҰЛТТЫҚ ҒЫЛЫМ АКАДЕМИЯСЫНЫН

АБАЙ АТЫНДАҒЫ ҚАЗАҚ ҰЛТТЫҚ

ПЕДАГОГИКАЛЫҚ УНИВЕРСИТЕТІНІҢ

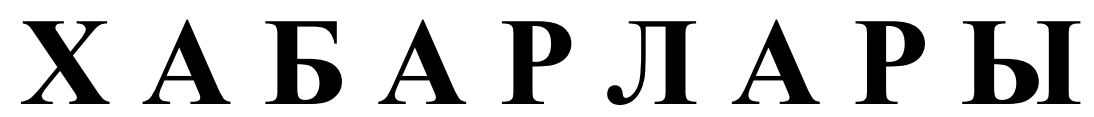

\section{ИЗВЕСТИЯ}

НАЦИОНАЛЬНОЙ АКАДЕМИИ НАУК РЕСПУБЛИКИ КАЗАХСТАН

КАЗАХСКИЙ НАЦИОНАЛЬНЫЙ

ПЕДАГОГИЧЕСКИЙ УНИВЕРСИТЕТ ИМ. АБАЯ

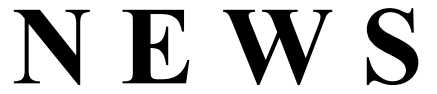

OF THE NATIONAL ACADEMY OF SCIENCES OF THE REPUBLIC OF KAZAKHSTAN

ABAY KAZAKH NATIONAL PEDAGOGICAL UNIVERSITY

ҚОҒАМДЫҚ ЖӘНЕ ГУМАНИТАРЛЫҚ ҒЫЛЫМДАР СЕРИЯСЫ

СЕРИЯ ОБЩЕСТВЕННЫХ И ГУМАНИТАРНЫХ НАУК

$\checkmark$

SERIES OF SOCIAL AND HUMAN SCIENCES

$$
5 \text { (321) }
$$

КЫРКУЙЕК - КАЗАН 2018 ж.

СЕНТЯБРЬ - ОКТЯБРЬ 2018 Г.

SEPTEMBER - OCTOBER 2018

1962 ЖЫЛДЫҢ ҚАНТАР АЙЫНАН ШЫҒА БАСТАҒАН

ИЗДАЕТСЯ С ЯНВАРЯ 1962 ГОДА

PUBLISHED SINCE JANUARY 1962

ЖЫЛЫНА 6 РЕТ ШЫҒАДЫ

ВЫХОДИТ 6 РАЗ В ГОД

PUBLISHED 6 TIMES A YEAR 
Ба с ре дактор

ҚР ҰҒА кұрметті мүшесі

Балықбаев Т.O.

Р е д а ц и я а лқ а сы:

экон. ғ. докторы, проф., ҚР ҰҒА академигі Баймұратов У.Б.; тарих ғ. докторы, проф., ҚР ҰҒА академигі Байпақов К.М.; филос. ғ.докторы, проф., ҚР ҰҒА академигі Есім Г.Е.; фил. ғ. докторы,, проф., ҚР ҰҒА академигі Қирабаев С.С.; эк. ғ. докторы, проф., ҚР ҰҒА академигі Кошанов А.К.; эк.ғ. докторы, проф., ҚР ҰҒА академигі Нәрібаев К.Н. (бас редактордың орынбасары); филос. ғ.докторы, проф., ҚР ҰҒА академигі Нысанбаев А.Н.; заң ғ. докторы, проф., ҚР ҰҒА академигі Сәбікенов С.Н.; заң ғ. докторы, проф., ҚР ҰҒА академигі Сүлейменов М.К.; эк. ғ. докторы, проф., ҚР ҰҒА академигі Сатыбалдин С.С.; тарих ғ. докторы, проф., ҚР ҰҒА академик Әбжанов Х.М.; тарих ғ. докторы, проф., ҚР ҰҒА корр. мүшесі Әбусеитова М.Х.; тарих ғ. докторы, проф., ҚР ҰҒА академик Байтанаев Б.А.; филол. ғ. докторы, проф., ҚР ҰҒА корр. мүшесі Жақып Б.А.; фил. ғ. докторы, проф., академик НАН РК Қалижанов У.К.; филол. ғ. докторы, проф., ҚР ҰҒА академик Қамзабекұлы Д.; тарих ғ. докторы, проф., ҚР ҰҒА академик Қожамжарова Д.П.; тарих ғ. докторы, проф., ҚР ҰҒА академик Койгелдиев М.К.; фил. ғ. докторы, проф., ҚР ҰҒА корр. мүшесі Кұрманбайұлы Ш.; тарих ғ. докторы, проф., ҚР ҰҒА корр. мүшесі Таймағанбетов Ж.К.; социол. ғ. докторы, проф., ҚР ҰҒА корр. мүшесі Шәукенова 3.К.; фил. ғ. докторы, проф., КР ҰҒА корр. мүшесі Дербісәлі А.; саяси. ғ. докторы, проф., Бижанов А.К., тарих ғ. докторы, проф., Кабульдинов 3.Е.; фил. ғ. докторы, проф., ҚР ҰҒА корр мүшесі Қажыбек Е.3.

\section{Р едакция ке н е с i:}

Молдова Республикасының ҰҒА академигі Белостечник Г. (Молдова); Әзірбайжан ҰҒА академигі Велиханлы Н. (Азербайджан); Тәжікстан ҰҒА академигі Назаров Т.Н. (Тәжікстан); Молдова Республикасының ҰҒА академигі Рошка А. (Молдова); Молдова Республикасының ҰҒА академигі Руснак Г. (Молдова); Әзірбайжан ҰҒА корр. мүшесі Мурадов Ш. (Әзірбайжан); Әзірбайжан ҰҒА корр. мүшесі Сафарова 3. (Әзірбайжан); э. ғ. д., проф. Василенко В.Н. (Украина); заң ғ. докт., проф. Устименко В.А. (Украина)

«Қазақстан Республикасы Ұлттық ғылым академиясының Хабарлары. Қоғамдық және гуманитарлық ғылымдар сериясы». ISSN 2224-5294

Меншіктенуші: «Қазақстан Республикасының Ұлттық ғылым академиясы» РҚБ (Алматы қ.)

Қазақстан республикасының Мәдениет пен ақпарат министрлігінің Ақпарат және мұрағат комитетінде 30.04.2010 ж. берілген № 10894-Ж мерзімдік басылым тіркеуіне қойылу туралы куәлік

Мерзімділігі: жылына 6 рет.

Тиражы: 500 дана.

Редакцияның мекенжайы: 050010, Алматы қ., Шевченко көш., 28, 219 бөл., 220, тел.: 272-13-19, 272-13-18, http://nauka-nanrk.kz. social-human.kz

(C) Қазақстан Республикасының Ұлттық ғылым академиясы, 2018

Типографияның мекенжайы: «Аруна» ЖК, Алматы қ., Муратбаева көш., 75. 
Главный редакто $p$

Почетный член НАН РК

T.O. Балыкбаев

Р е дак ци онн а я коллег и я:

докт. экон. Н., проф., академик НАН РК У.Б. Баймуратов; докт. ист. н., проф., академик НАН РК К.М. Байпаков; докт. филос. Н., проф., академик НАН РК Г.Е. Есим; докт. фил. Н., проф., академик НАН РК С.С. Кирабаев; докт. экон. Н., проф., академик НАН РК А.К. Кошанов; докт. экон. Н., проф., академик НАН РК К.Н. Нарибаев (заместитель главного редактора); докт. филос. н., проф., академик НАН РК А.Н. Нысанбаев; докт. юр. Н., проф., академик НАН РК С.Н. Сабикенов; докт. юр. н., проф., академик НАН РК М.К. Сулейменов; докт. экон. Н., проф., академик НАН РК С.С. Сатубалдин; докт. ист. н., проф., академик НАН РК Х.М. Абжанов; докт. ист. н., проф., чл.-корр. НАН РК М.Х. Абусеитова; докт. ист. н., проф., академик НАН РК Б.А. Байтанаев; докт. фил. н., проф., чл.-корр. НАН РК Б.А. Жакып; докт. фиолол. н., проф., академик НАН РК У.К. Калижанов; докт. фил. н., проф., академик НАН РК Д. Камзабекулы; докт. ист. н., проф., академик НАН РК Д.П. Кожамжарова; докт. ист. н., проф., академик НАН РК М.К. Койгельдиев; докт. филол. н., проф., чл.-корр. НАН РК Ш. Курманбайулы; докт. ист. н., проф., чл.корр. НАН РК Ж.К. Таймаганбетов; докт. социол. н., проф., чл.-корр. НАН РК З.К. Шаукенова; д. филол. н., проф., чл.-корр. НАН РК А. Дербисали; доктор политических наук, проф., Бижанов А.К.; доктор ист. наук, проф., Кабульдинов 3.Е.; доктор филол. н., проф., член-корр. НАН РК Қажыбек Е.3.

Р е дак ци онны й с ов е т

академик НАН Республики Молдова Г. Белостечник (Молдова); академик НАН Азербайджанской Республики Н. Велиханлы (Азербайджан); академик НАН Республики Таджикистан Т.Н. Назаров (Таджикистан); академик НАН Республики Молдова А. Рошка (Молдова); академик НАН Республики Молдова Г. Руснак (Молдова); чл.-корр. НАН Азербайджанской Республики Ш. Мурадов (Азербайджан), член-корр. НАН Азербайджанской Республики 3.Сафарова (Азербайджан); д. э. н., проф. В.Н. Василенко (Украина); д.ю.н., проф. В.А. Устименко (Украина)

Известия Национальной академии наук Республики Казахстан. Серия общественных и гуманитарных наук. ISSN 2224-5294

Собственник: РОО «Национальная академия наук Республики Казахстан» (г. Алматы)

Свидетельство о постановке на учет периодического печатного издания в Комитете информации и архивов

Министерства культуры и информации Республики Казахстан № 10894-Ж, выданное 30.04.2010 г.

Периодичность 6 раз в год

Тираж: 500 экземпляров

Адрес редакции: 050010, г. Алматы, ул. Шевченко, 28, ком. 219, 220, тел. 272-13-19, 272-13-18, www:nauka-nanrk.kz / social-human.kz

(C) Национальная академия наук Республики Казахстан, 2018 г.

Адрес типографии: ИП «Аруна», г. Алматы, ул. Муратбаева, 75

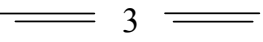


Chief Editor

\section{Honorary member of NAS RK \\ Balykbayev T.O}

Editorial board:

Doctor of economics, prof, academician of NAS RK Baimuratov U.B.; doctor of history, prof, academician of NAS RK Baipakov K.M.; doctor of philosophy, prof, academician of NAS RK Esim G.E.; doctor of philology, prof, academician of NAS RK Kirabayev S.S.; doctor of economics, prof, academician of NAS RK Koshanov A.K.; doctor of economics, prof, academician of NAS RK Naribayev K.N. (deputy editor-in-chief); doctor of philosophy, prof, academician of NAS RK Nyssanbayev A.N.; doctor of law, prof, academician of NAS RK Sabikenov S.N.; doctor of law, prof, academician of NAS RK Suleymenov M.K.; doctor of economy, prof, academician of NAS RK Satybaldin S.S.; doctor of history, prof, academician of NAS RK Abzhanov H.M; doctor of history, prof, corresponding member of NAS RK Abuseitova M.H.; doctor of history, prof, academician of NAS RK Baitanaev B.A.; doctor of philology, prof, corresponding member of NAS RK Zhakyp B.A.; doctor of philology, prof, academician of NAS RK Kalizhanov U.K.; doctor of philology, prof, academician of NAS RK Hamzabekuly D.; doctor of history, prof, academician of NAS RK Kozhamzharova D.P.; doctor of history, prof, academician of NAS RK Koigeldiev M.K.; doctor of philology, prof, corresponding member of NAS RK Kurmanbaiuly Sh.; doctor of history, prof, academician of NAS RK Taimaganbetov J.K.; doctor of sociology, prof, corresponding member of NAS RK Shaukenova Z.K.; doctor of philology, prof, corresponding member of NAS RK Derbisali A.; doctor of political science, prof Bizhanov A.K; doctor of History, prof Kabuldinov Z.E.; doctor of philology, prof, corresponding member of NAS RK Kazhybek E.Z.

\section{Editorial staff:}

Academician NAS Republic of Moldova Belostechnik.G (Moldova); Academician NAS Republic of Azerbaijan Velikhanli N. (Azerbaijan); Academician NAS Republic of Tajikistan Nazarov T.N. (Tajikistan); Academician NAS Republic of Moldova Roshka A. (Moldova) Academician NAS Republic of Moldova Rusnak G. (Moldova); Corresponding member of the NAS Republic of Azerbaijan Muradov Sh. (Azerbaijan); Corresponding member of the NAS Republic of Azerbaijan Safarova Z. (Azerbaijan); Associate professor of Economics Vasilenko V.N. (Ukraine), Associate professor of Law Ustimenko V.A. (Ukraine)

News of the National Academy of Sciences of the Republic of Kazakhstan. Series of Social and Humanities. ISSN 2224-5294

Owner: RPA "National Academy of Sciences of the Republic of Kazakhstan" (Almaty)

The certificate of registration of a periodic printed publication in the Committee of information and archives of the Ministry of culture and information of the Republic of Kazakhstan N 10894-Ж, issued 30.04.2010

Periodicity: 6 times a year

Circulation: 500 copies

Editorial address: 28, Shevchenko str., of. 219, 220, Almaty, 050010, tel. 272-13-19, 272-13-18, www:nauka-nanrk.kz / social-human.kz

(C) National Academy of Sciences of the Republic of Kazakhstan, 2018

Address of printing house: ST "Aruna", 75, Muratbayev str, Almaty 
N E W S

OF THE NATIONAL ACADEMY OF SCIENCES OF THE REPUBLIC OF KAZAKHSTAN

SERIES OF SOCIAL AND HUMAN SCIENCES

ISSN 2224-5294

https://doi.org/10.32014/2018. 2224-5294.2

Volume 5, Number 321 (2018), $12-18$

UDK 336.7

L.M. Sembiyeva ${ }^{1}$, D.M. Mazhitov ${ }^{1}$, M.E. Karpitskaya ${ }^{2}$ D. M. Khamitova ${ }^{3}$

${ }^{1}$ L.N. Gumilyov Eurasian National University, Astana, Kazakhstan;

${ }^{2}$ Y. Kupala Grodno State University, Grodno, Republic of Belarus;

${ }^{3}$ Pavlodar State Pedagogical University, Pavlodar, Kazakhstan sembiyeva@mail.ru, mazhitov.daurenbek01@gmail.com,

karpitskaya@mail.ru, dariga1979@mail.ru

\title{
TRANSFORMATION OF THE MONETARY SYSTEM OF THE EURASIAN ECONOMIC UNION COUNTRIES IN THE CONDITIONS OF MODERNIZATION OF THE ECONOMY
}

\begin{abstract}
Despite a significant increase in research and development, R\&D, financing, Kazakhstan still has a low level of technological development compared to other countries, as evidenced by its position in world statistics. In the modernization of the economy, financial institutions and the entire monetary system play an important role, respectively, issues related to the development and reform of the credit system of the Republic of Kazakhstan and the implementation of monetary policy are becoming increasingly important.
\end{abstract}

Keywords: credit system, monetary policy, Eurasian Economic Union, modernization of economy, transformation.

Influence of the modern world economy on the Eurasian Economic Union countries, connected with the revolution in the field of informatization and digitization, the development of new technologies. As the experts note, the processes of the "fourth industrialization" go inextricably with the growth of the development of the service sector, the increase in risks in the global economy, the transformation of the structure of global production, income distribution, the emergence of new centers of political and economic influence and aggravation of interregional competition.

In 2017, the countries of the Eurasian Economic Union demonstrated a strong recovery of economic activity after the consequences of the crisis of 2014. The pace of economic growth in all the Eurasian Economic Union member states, except for Russia, was higher than the forecasts of national authorities and international economic organizations. Following the results of 2017, Armenia, Kyrgyzstan and Kazakhstan demonstrated the highest growth rates $-7.5 \%, 4.6 \%$ and $4.0 \%$, respectively. At the same time, GDP growth rates in Belarus and Russia relative to other Eurasian Economic Union member states remain low: $2.4 \%$ and $1.5 \%$ [2]. As you know, in Kazakhstan, the financial and credit policy in 2017 was carried out in conditions of macroeconomic stability and recovery of economic growth rates.

In 2017 there was a significant acceleration in the growth of the economy of Kazakhstan in comparison with 2016. According to official data, in 2017, Kazakhstan's GDP reached 51.6 trillion tenge in current prices, having increased by $4.0 \%$ in real terms [4]. At the same time, an important contribution to GDP growth was made by the industry, whose production growth in 2010 amounted to $7.1 \%$. It should be noted that the positive growth of the economy of Kazakhstan was facilitated by an increase in investments in fixed assets, in 2017 the growth was 5.5\%, and from 2013 to 2017 it amounted to KZT2,676.6 billion, or 44.1\%, which is ensured an increase in the volume of investments from own funds, whose share increased from $51.7 \%$ in 2013 to $68.7 \%$ in 2017. In general, and importantly, investments in fixed assets in 2017 have grown in all Eurasian Economic Union member states.

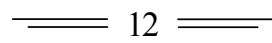




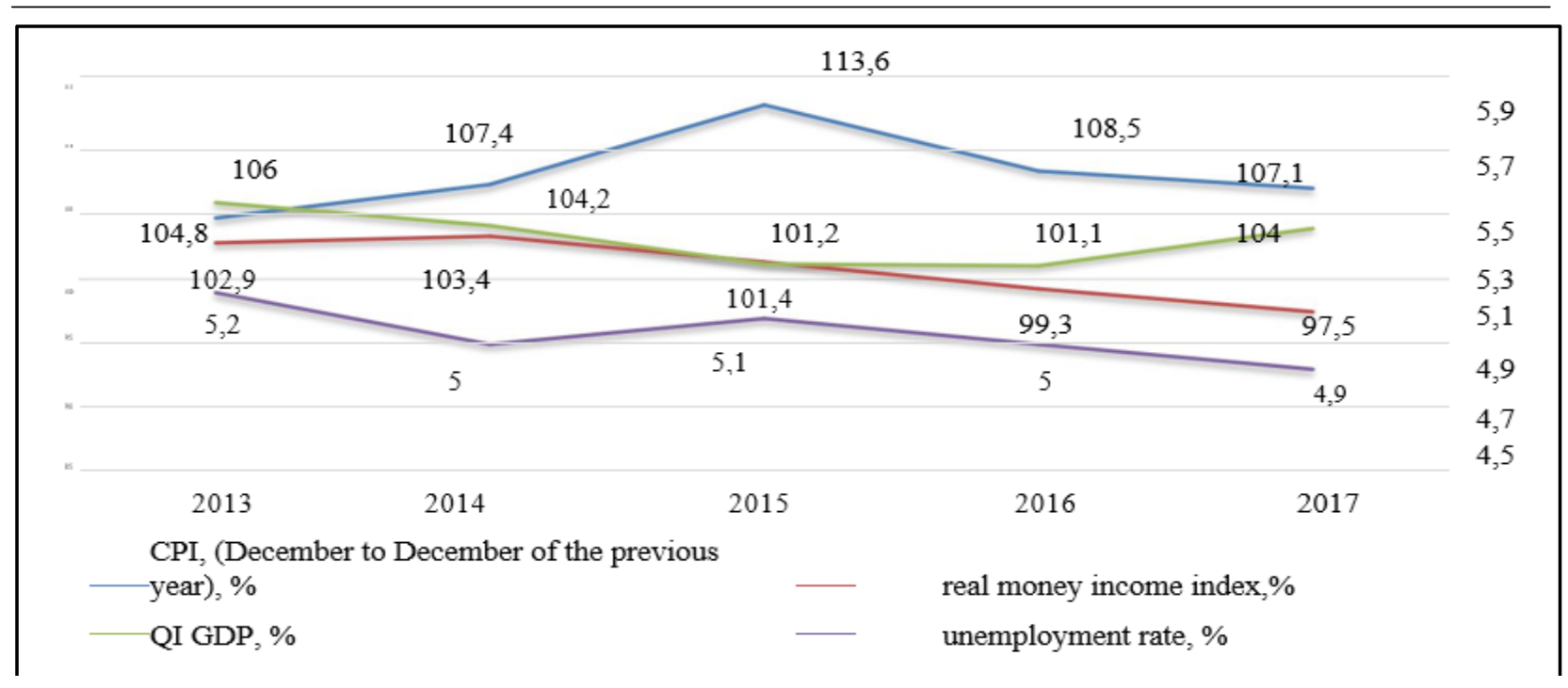

Figure 1 - Dynamics of the main macroeconomic indicators 2013 - 2017 [3]

The priorities of the modernization of the economy of Kazakhstan in the Strategy 2050 to ensure technological breakthroughs and accelerated development of the economy, naturally, can be realized to the full extent if there is a radical turn towards increasing innovation activity of Kazakhstan enterprises. In turn, this will require, above all, increasing the effectiveness of state scientific, technological and innovation policies.

The given tables testify to low innovative activity of the Kazakhstan industrial enterprises. In 2017, out of 30854 enterprises of the republic, only 2974 economic entities have technological innovations. The innovative activity of enterprises in Kazakhstan in 2016 was 14\%. At the same time, in the long term, until 2020, Kazakhstan plans to raise the share of innovation-active enterprises to $20 \%$ of all business entities. For comparison: in 2016 the share of innovation-active enterprises in Switzerland was - 60.2\%, in Belgium, Germany, Finland - from 50\% [6].

Table 1 - Analysis of indicators that characterize the innovative activity of enterprises in Kazakhstan in 2012-2017

\begin{tabular}{|c|c|c|c|c|c|c|c|}
\hline Indicators & Measurement & 2012 & 2013 & 2014 & 2015 & 2016 & 2017 \\
\hline Number of respondents & Human & 21452 & 22070 & 24068 & 31784 & 31077 & 30854 \\
\hline $\begin{array}{l}\text { Number of innovation- } \\
\text { active enterprises }\end{array}$ & Ent. & 1622 & 1774 & 1940 & 2585 & 2879 & 2974 \\
\hline $\begin{array}{l}\text { Share of innovation-active } \\
\text { enterprises }\end{array}$ & $\%$ & 7,6 & 8,1 & 10 & 12 & 14 & $\mathrm{n} / \mathrm{a}$ \\
\hline $\begin{array}{l}\text { Level of activity in the } \\
\text { field of innovations }\end{array}$ & $\%$ & 7,6 & 8,0 & 8,1 & 8,1 & 9,3 & 9,6 \\
\hline $\begin{array}{l}\text { The volume of innovative } \\
\text { products }\end{array}$ & Bln. tenge & 379,0 & 578,3 & 580,4 & 377,2 & 445,8 & 844,7 \\
\hline $\begin{array}{l}\text { Share of innovative } \\
\text { products in GDP }\end{array}$ & $\%$ & 1,25 & 1,64 & 1,46 & 0,92 & 0,95 & 1,63 \\
\hline
\end{tabular}

Despite the fact that the number of innovative-active enterprises is growing, their share in the total number of respondents remains low. This also affects the volume of innovation products, which grew by $17.6 \%$, but if we consider this indicator in relation to GDP, it shows a slight increase in $2017(1.63 \%)$ compared to $2012(1.25 \%)$. This figure is planned to increase to $2.5 \%$ by 2020 in the total GDP.

Most of all R \& D spending in Kazakhstan is spent by the state, occupying $35.9 \%$ in domestic R \& D expenditures. Own funds account for 28.2\%. In general, the National Agency for Technological Development is engaged in financing innovative activity in Kazakhstan [7]. 
The largest share in the structure of costs for research and development is the costs of applied research. For the period 2012-2016. the total amount of all funds allocated to finance R \& D in the Republic of Kazakhstan amounted to KZT 316 billion.

Despite a significant increase in R \& D financing, Kazakhstan still has a low level of technological development compared to other countries, as evidenced by its position in world statistics.

It should also be noted that $40 \%$ of all enterprises in Kazakhstan are worn out. Accordingly, the decrease in the rate of renewal of enterprise funds gives a negative impact of economic modernization.

In the modernization of the economy, financial institutions and the entire monetary system play an important role, respectively, issues related to the development and reform of the credit system of the Republic of Kazakhstan are becoming increasingly important.

Table 2 - Analysis of the structure and dynamics of R\&D expenditures by sources of financing for 2012-2017, billion tenge

\begin{tabular}{|c|c|c|c|c|c|c|c|}
\hline Indicators & 2012 & 2013 & 2014 & 2015 & 2016 & 2017 & $\begin{array}{c}\text { Growth rate of } 2017 \\
\text { as } \% \text { of } 2012\end{array}$ \\
\hline Gross costs, total & 68,5 & 73,9 & 73,6 & 86,6 & 89,5 & 92,7 & 135,5 \\
\hline spec. weight, \% & 100,0 & 100,0 & 100,0 & 100,0 & 100,0 & 100,0 & \\
\hline Internal costs & 50,9 & 61,7 & 66,3 & 69,3 & 66,6 & 68,9 & 135,4 \\
\hline spec. weight, $\%$ & 74,9 & 83,5 & 90,1 & 80,0 & 74,4 & 74,3 & \\
\hline \multicolumn{8}{|l|}{ including: } \\
\hline budget resources & 30,7 & 39,3 & 43,3 & 40,7 & 35,4 & 35,9 & 116,9 \\
\hline spec. weight, \% & 59,8 & 63,7 & 65,3 & 58,7 & 39,6 & 38,7 & \\
\hline own funds & 17,1 & 17,8 & 19,9 & 25,4 & 26,4 & 28,2 & 164,9 \\
\hline spec. weight, \% & 33,3 & 28,8 & 30,0 & 36,7 & 29,5 & 30,4 & \\
\hline $\begin{array}{l}\text { foreign } \\
\text { investment }\end{array}$ & 0,3 & 0,5 & 0,5 & 1,3 & 1,0 & 1,3 & 433,3 \\
\hline spec. weight, \% & 0,6 & 0,8 & 0,8 & 1,9 & 1,1 & 1,4 & \\
\hline other means & 3,2 & 4,1 & 2,7 & 2 & 3,8 & 3,4 & 106,3 \\
\hline spec. weight, \% & 6,2 & 6,6 & 4,1 & 2,9 & 4,2 & 3,7 & \\
\hline External costs & 17,2 & 12,2 & 7,2 & 17,3 & 22,9 & 23,8 & 138,4 \\
\hline spec. weight, \% & 25,1 & 16,5 & 9,8 & 20,0 & 25,6 & 25,7 & \\
\hline
\end{tabular}

Today, serious structural changes in the credit system of developed countries are becoming evident: a reduction in the role of banks and an increase in the influence of other credit and financial institutions (insurance companies, pension funds, investment companies, etc.). This, as a rule, is expressed both in the growth of the total number of new credit and financial institutions and in the increase in their share in the total assets of all credit and financial institutions.

The study of credit system problems has traditionally been reduced to analyzing either monetary problems or problems of banks. Although, as we know, the credit system is much broader than the banking system.

The credit system is known to play an important role, redistributing resources in the economy and the purpose of this process is, first of all, financing capital investments in the development of new industries and innovations.

Scientists are unanimous in the opinion that the modern credit system should be viewed as a set of various financial institutions operating in the market of loan capital and carrying out the accumulation and mobilization of money capital. [8,9,10,11].

According to official data, about 1000 banks with a capital of 250 billion dollars are functioning on the territory of the states that make up the Eurasian Economic Union, the aggregate reserves of credit organizations make up over 2 trillion. dollars, and the stock market exceeds 1 trillion. dollars. The volume of mutual investments of the EEA countries amounted to 1.9 billion dollars. The aggregate market of participating countries is estimated at 170 million people and accounts for $2.5 \%$ of world GDP [2]. 
As you know, the EU countries are significantly ahead of the Eurasian Economic Union countries in terms of their financial institutions. At the same time, Austria has the largest number of credit organizations per 1 million people ( 88 units), Germany (22 units) and Poland (18 units) are on the second place.

Of the Eurasian Economic Union countries, Armenia (7 units), Russia (4.7 units) and Kyrgyzstan (4 units) demonstrate the greatest security by credit organizations.

A more objective estimate of the activity of financial organizations is the ratio of assets of financial institutions to percentages of GDP. This indicator allows you to determine whether economic entities are satisfied with their financial needs. The highest figure in France, the lowest in Kyrgyzstan, Kazakhstan in the penultimate place of the sample of countries.

As for the structure of the credit system, nevertheless, the dominant role of the banking sector is characteristic for all the Eurasian Economic Union countries.

The trend of recent years shows that the number of banks in the Eurasian Economic Union member countries is gradually decreasing. The largest decrease occurred in Russia. The reason for the closure is different: violations of financial legislation - unreliable reporting, inadequate capital, inability to meet the claims of creditors for their obligations, could not reach the minimum capital, due to restructuring - mainly due to mergers and acquisitions.

In terms of assets and liabilities of banks among the countries participating in the Eurasian Economic Union Kazakhstan ranks 2nd in Russia, although it lags far behind it.

If we compare the competition in the credit markets with the nearest economies, then in comparison to the markets of Russia and Belarus, the comparison will be in favor of Kazakhstan. In Belarus, the market is essentially a monopoly - two state-owned banks occupy more than half of the entire lending market, while the share of the largest Belarusbank is $37.8 \%$, which is almost 1.5 times higher than Kazkommertsbank. Dominating in Russia, Sberbank controls $34.4 \%$ of the lending market, and the next VTB $-11.2 \%$. All this led to the fact that the level of monopolization in Russia is $26.7 \%$ higher than in Kazakhstan.

Table 3 -Dynamics of the number of banks in the EAES, 2013-2018, units

\begin{tabular}{|c|c|c|c|c|c|c|}
\hline & 2013 & 2014 & 2015 & 2016 & 2017 & 2018 \\
\hline \multicolumn{7}{|c|}{ Armenia } \\
\hline Banks & 22 & 22 & 22 & 21 & 16 & 14 \\
\hline \multicolumn{7}{|l|}{ Belarus } \\
\hline Banks & 31 & 31 & 26 & 26 & 25 & 25 \\
\hline \multicolumn{7}{|c|}{ Kazakhstan } \\
\hline Banks & 38 & 38 & 35 & 35 & 34 & 32 \\
\hline \multicolumn{7}{|c|}{ Kyrgyzstan } \\
\hline Banks & 24 & 24 & 24 & 25 & 25 & 25 \\
\hline \multicolumn{7}{|l|}{ Russia } \\
\hline Banks & 923 & 834 & 681 & 680 & 623 & 561 \\
\hline \multicolumn{7}{|c|}{ Eurasian Economic Union } \\
\hline Total & 1038 & 949 & 788 & 787 & 723 & 657 \\
\hline
\end{tabular}

Thus, Kazakhstan should pay more attention to the experience of Turkey, which proved the possibility with a small number of banks to provide a more free financial market than the Russian banking sector, 630 of whose participants could not form a competitive environment.

The most developed of all sectors of the credit system in Kazakhstan is the banking sector. As of the beginning of 2018, the banking sector is represented by 32 second-tier banks, of which 15 are banks with foreign participation, including 11 subsidiary banks.

In Kazakhstan at the moment there are major mergers. Of course, consolidation will have a positive impact on the financial system. Within the WTO, commercial banks in Kazakhstan have to compete with the largest financial institutions. And naturally, the earlier the risks of poor-quality assets and poor management are reduced, the easier it will be to survive in a competitive environment.

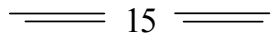


The liabilities of the second-tier banks of the Republic of Kazakhstan are 22,716.3 billion tenge, an increase for $2016-6.7 \%$. In the total liabilities of second-tier banks, the largest share is occupied by customer deposits $-76.0 \%$ and issued securities $-7.8 \%$ [12].

Despite the measures taken for long-term funding of second-tier banks, their assets as of January 1 , 2018 decreased by $5.5 \%$ and amounted to KZT $24,157.9$ billion.

The share of STB (second tier banks) assets as a percentage of GDP as of January 1 of this year. decreased to $49.9 \%$ against $54.4 \%$ as of January 1, 2017 (61.4\% as of January 1, 2016).

The quality of the loan portfolio does not improve, loans with overdue debts over 90 days as of January 1, 2018 compared to the same date in 2017 increased to $9.3 \%$ of the loan portfolio (as of January 1, $2016-8 \%$, as of January 1, $2017-6.7 \%$ ) and amounted to KZT 1265.2 billion.

Over the period from 2013 to 2017, the volume of loans extended to the economy of STB increased slightly from 11.3 trillion. KZT (at the end of 2013) to 12.7 trillion. tenge (at the end of 2017). The trend of declining lending to GDP is continuing (from $31.4 \%$ in 2013 to $24.6 \%$ in 2017).

There is a decrease in lending to STB of the real sector of the economy against the background of increased investment in securities.

Thus, from the analysis we see that in order to ensure competition in the financial services market, it is necessary to pay special attention to the development of non-banking financial institutions.

The countries of the Eurasian Economic Union want to create a common financial market, but for this it is necessary to gradually introduce special integration tools and go through all the stages of Eurasian integration.

Effective integration of financial markets requires greater coordination of monetary policy among the member states of the Eurasian Economic Union. In this regard, the provision of coordination in the monetary sphere is the main task for the implementation of the full integration of the economies of the Eurasian Economic Union member countries.

However, there are differences in the monetary policy of the member countries. So, if a flexible exchange rate is observed in Russia, Belarus and Kyrgyzstan, then Armenia actually uses a stabilized exchange rate against the US dollar, limiting the fluctuations of the dram within a two percent horizontal corridor. Kazakhstan for a long time used the mode of targeting the exchange rate with a sliding link, but in 2015 devalued the tenge and announced the transition to the inflation targeting regime with a floating rate.

To accelerate the coordination of monetary policies of countries determine the overall plans of countries to move to inflation targeting with a flexible exchange rate. At the same time, announced medium-term inflation targets largely coincide.

Table 4 - Inflation targets for the member-states of the Eurasian economic union for 2020

\begin{tabular}{|c|c|}
\hline Country & Medium-term inflation targets for 2020 (\%) \\
\hline Armenia & 4 \\
\hline Belarus & 5 \\
\hline Kazakhstan & $3-4$ \\
\hline Kyrgyzstan & $5-7$ \\
\hline Russia & 4 \\
\hline
\end{tabular}

In addition, most of the member states of the Eurasian Economic Union declare plans to move to inflation targeting with a flexible exchange rate, but due to the different speed of implementation of the announced changes, differences in approaches to the implementation of monetary policies remain.

The dynamics of inflationary processes in each of the countries of the Eurasian Economic Union have both general trends caused by global economic factors and individual characteristics determined by differences in the internal structure of each economy. It should be noted that in 2007-2008 and in 20102013 there is a strong positive correlation between price level changes in the analyzed countries, which is explained by the growth of world food prices in 2007 and energy resources in 2010.

Starting from the second half of 2014, characterized as a period of active decline in world oil prices, inflationary processes in the Eurasian Economic Union countries began to show multidirectional

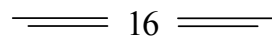


dynamics. In countries, net importers of oil (Belarus, Armenia and Kyrgyzstan), inflation began to decline, including in Armenia and Kyrgyzstan since 2016 began to develop deflationary processes.

At the same time, Russia and Kazakhstan, which are net exporters of hydrocarbon raw materials, following the fall in world oil prices, were forced at different times to switch to free exchange rates of their national currencies as part of the implementation of the inflation targeting policy, as a result of which the exchange rates of the Russian ruble and Kazakhstan tenge to world currencies have significantly depreciated. In turn, the increased effect of the transfer of the exchange rate caused a sharp acceleration of inflationary processes in these countries. With the adaptation of the economies of Russia and Kazakhstan to new conditions and stabilization of the exchange rate of the ruble and tenge, inflationary processes in these countries have also stabilized. And in October 2017, the inflation of the Eurasian Economic Union countries is close to each other in importance (Armenia - 101\%, Belarus - 103.9\%, Kazakhstan - 105.4\%, Kyrgyzstan - 102\%, Russia - 101.9\%) [13].

Thus, CPI in the Eurasian Economic Union countries tend to converge. This phenomenon is favorable for the use within the framework of the Eurasian Economic Union close target inflation targets for the purpose of coordinating the monetary policies of member countries. However, the problems of high dollarization, high inflationary and devaluation expectations, inflationary processes of different levels and volatility impede the implementation of an effective monetary policy in the Eurasian Economic Union countries.

Consequently, the participation of Kazakhstan in the Eurasian Economic Union has a direct impact on the development of the financial and credit system as a whole, since the activities of the Eurasian Economic Union are aimed at creating conditions for the stable development of the economies of the member states in order to improve the living standards of their population, the desire to form a single market for goods, services, capital and labor resources within the Union, comprehensive modernization, cooperation and increasing competitiveness of national economies in the global economy.

Accordingly, it is necessary:

- reduction of inflation in the Eurasian Economic Union member countries to the established target level and its subsequent maintenance within the established target;

- Gradual transition of member countries to inflation targeting with a flexible exchange rate to accelerate coordination in the monetary sphere.

To successfully overcome macroeconomic challenges, the countries of the Eurasian Economic Union need cooperation to develop a response strategy at the supranational level, which is to use the new competitive advantages of the Eurasian Economic Union member countries in the non-primary sectors of the economy and to form their own center of power.

\section{REFERENCES}

[1] Annual Report for 2017 "On the Results and Prospects of the Social and Economic Development of the Member States of the Eurasian Economic Union and the Measures made by the Eurasian Economic Union Member States in the field of macroeconomic policy"2017[Electronic resource]: http://www.eurasiancommission.org/(in Eng)

[2] Official website of the Department of Statistics of the EAEC// [Electronic resource]:http://www.eurasiancommission.org/en/act/integr_i_makroec/dep_stat/fin_stat/stat_tables/Pages/default.aspx(in Eng)

[3] The official website of the Accounts Committee for Control over the Executionof the Republican Budget //[Electronic resource]http://esep.kz/rus/show1/article/26

[4] Official site of the Ministry of Finance of the RK//[Electronic resource]http:www.minfin.gov.kz(in Rus)

[5] Official site of the Committee on Statistics of the Ministry of Education and Science of the Republic of Kazakhstan // stat.gov.kz(in Rus)

[6] Fridlyanova S.Yu.(2017)Innovative activity of industrial production organizations.[Innovatsionnaya aktivnost' organizatsij promyshlennogo proizvodstva.]// Institute of Statistical Studies and Knowledge Economy. HSEC [Institut statisticheskikh issledovanij i ehkonomiki znanij. NIU VSHEH]:1-3(in Rus)

[7] The official site of the Analytical Analyst of the NATR [Electronic resource]: http://analytics.natd.gov.kz

[8] SeytkasimovG., MusinaA., Albekova S.S.(2015) Models and mechanisms of interaction of financial intermediaries in Kazakhstan: Monograph. Astana: CPI KazUEFMT. ISBN: 978-601-7528-25-6

[9] Iskakova Z.D. (2014)Theoretical bases of finance, credit and the role of the financial system in the development of the Strategy of Kazakhstan. Almaty. ISBN: 978-601-80402-1-4

[10]Kuchukova N.K.(2011) Macroeconomic aspects of reforming the financial and credit system over the years of Kazakhstan's independence: prerequisites, trends and prospects for development. Monogram.Astana: UzD KazMEDFET.

[11] Sembiyeva L.M.(2016) Theory and practice of inflation: modern approaches to assessment and regulation in the context of globalization. Monogram..Almaty: Evero.ISBN:978-691-310-782-0 
[12] The official website of the National Bank of the Republic of Kazakhstan [Electronicresource]: http://www.nationalbank.kz/document/?docid=5106\&switch =rus (in Rus)

[13]Demidenko M.V. (2017)Monetary policy of the EEA member states: current status and prospects for coordination.Russia, Saint-PetersburgISBN:978-5-906-157-33-1

\author{
Л.М. Сембиева ${ }^{1}$, Д.М. Мажитов ${ }^{1}$, М.Е.Карпицкая ${ }^{2}$, Д.М. Хамитова ${ }^{3}$ \\ 1 Л.Н. Гумилев атындағы Еуразия Ұлттық университеті, Астана, Казақстан Республикасы; \\ ${ }^{2}$ Я. КупалаатындағыГродномемлекеттікуниверситеті, Гродно, БеларусьРеспубликасы; \\ ${ }^{3}$ Павлодармемлекеттікпедагогикалықуниверситеті, Павлодар, КазақстанРеспубликасы
}

\title{
ЭКОНОМИКАНЫ ЖАНҒЫРТУ ЖАҒДАЙЫНДАҒЫ ЕАЭО ЕЛДЕРІНІН МОНЕТАРЛЫК ЖУЕСІНІН ӨЗГЕРУІ
}

\begin{abstract}
Аннотация. Әлемдік статистикадағы ұстанымыменбайланысты,ҒЗТКЖ-ды қаржыландырудың едәуір өсуіне қарамастан, Қазақстан басқа елдермен салыстырғанда технологиялық тұрғыдан дамудың әлі де төмен деңгейінде.Экономиканы модернизациялау кезінде қаржылық институттар мен барлық монетарлық жүйесі маңызды рөл атқарады. Қазақстан Республикасының несие жүйесін дамыту және реформалау, монетарлық саясатын жүзеге асыру мәселелеріне байланысты сұрақтардың өзектілігі артуда.
\end{abstract}

Түйін сөздер: несие саясаты, монетарық саясат, ЕАЭО, экономиканы жаңғырту, трансформация

УДК 336.7

\section{Л.М.Сембиева ${ }^{1}$, Д.М.Мажитов ${ }^{1}$, М.Е. Карпицкая ${ }^{2}$, Д.М. Хамитова ${ }^{3}$}

${ }^{1}$ Евразийский национальный университет имени Л.Н.Гумилева, Астана, Республика Казахстан;

${ }^{2}$ Гродненский государственный университет имени Я. Купалы, Гродно, Республика Беларусь;

${ }^{3}$ Павлодарский Государственный педагогический университет, Павлодар, Республика Казахстан

\section{ТРАНСФОРМАЦИЯ МОНЕТАРНОЙ СИСТЕМЫ СТРАН ЕАЭС В УСЛОВИЯХ МОДЕРНИЗАЦИИ ЭКОНОМИКИ}

Аннотация. Несмотря на значительный рост финансирования НИОКР, Казахстан все же имеет низкий уровень технологического развития по сравнению с другими странами, о чем свидетельствует его положение в мировой статистике.В модернизации экономики большую роль играют финансовые институты и вся монетарная система, соответственно вопросы, связанные с развитием и реформированием кредитной системы республики Казахстан и проведением монетарной политики, приобретают все большую актуальность.

Ключевые слова: кредитная система,монетарная политика, ЕАЭС, модернизация экономики, трансформация.

Information about the authors:

Sembiyeva Lyazzat Myktybekovna - Doctor of Economic Sciences, Professor, L. N. Gumilyov Eurasian National University, https://orcid.org/0000-0001-7926-0443;

Mazhitov Daurenbek - Candidate of Economic Sciences, Associate Professor, L. N. Gumilyov Eurasian National University;

Karpitskaya Marina Evgenievna - Candidate of Economic Sciences, Associate Professor, Dean of the Faculty of Economics and Management Yanka Kupala Grodno State University The Republic of Belarus, Grodno;

Khamitova Dariga Mejramovna - Candidate of economic sciences,Associate Professor, Pavlodar State Pedagogical University,Pavlodar, Republic of Kazakhstan 


\section{МАЗМҰНЫ}

Алтыбаева С.М., Савындыков Е.С. Көркем мәтін құрылымындағы мифопоэтикалық модельдеу және мәдени код...... 5 Сембиева Л.М., Мажитов Д.М., Карпиикая М.Е., Хамитова Д.М. Экономиканы жаңғырту жағдайындағы ЕАЭО елдерінің монетарлық жүесінін өзгеруі .....

Құлсариева А.Т., Султанова М.Э., Шайгозова Ж.Н. Фольклор және сәйкестілік: Қазақстанның қазіргі заманғы

мәдениетіндегі тарих, жады және аңыз шығармашылығы ........................................................................................... 19

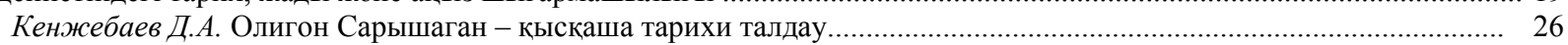

АбдулинаГ.А., БазарбаевА.Г. Ұйымдардағы адам ресурстарын басқарудың заманауи тұжырымдамалары................ 33

Авыбаев А.Н., Адибаева А.К. Геноцид туралы БҰҰ Конвенциясының қатысушы мемлекеттердің қылмыстық

заңнамаларындағы имплементациялық тетіктері: жалпы салыстырмалы талдау............................................................ 39

Ахметжанов Б., Тәжібекова К.Б., Шаметова А.А. Қазақстан көлік өнеркәсіптің дамуын талдау............................. 44

Аюпова 3.К., Құсайынов Д.Ө. Тәуелсіздік жағдайындағы қазақстан республикасының конституциялық-құқықтық

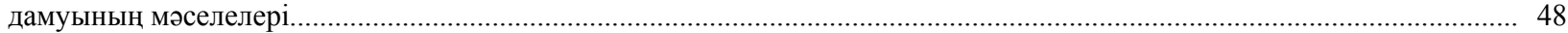

Нурпеисова А.А., Рей И.Ю., Бижанов Д.Т., Тлеужанова Д.А. Инновациялық өндірісді жасаудың процесін

бақылауының негізгі элементтері

Гиздатов Г.Г. Қазақстандық дискурсының құрылымы психолингвистиякалық зерттеу .

Ищанова Р.К. Мемлекеттік шығындарды басқару - мемлекеттің қаржылық тұрақтылығын қамтамасыз ету.............. 64

Мадышева А.М. Бикенова А.С., Елеусиз Л.Т. Білім саласындағы туристік қызметтер............................................. 68

Ескалиева А. Ж., Баймуханова М.Т., Ахмурзина Д.О. Әлеуметтік сала адам капиталының сапасын қолдаудың

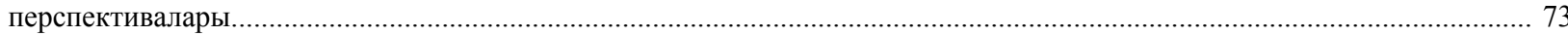

Мархаева Б.А., Козбахова Д.Л. Жауапкершілік орталық және трансферттік баға белгілеу............................................ 79

Сабирова Р.К., Утепкалиева К.М., Кабаков С.Б. Қазақстандағы ауыл шаруашылығы экономикасының

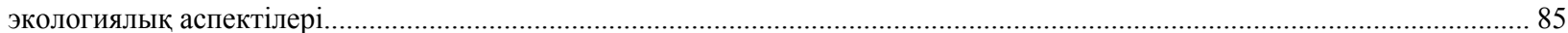

Тлесова Э., Хойч А., Кураш Н. Қазақстан республикасының ғылыми инновациялық потенциясы және оның

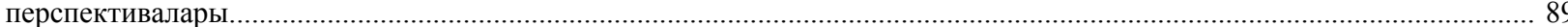

Хамитхан Н. Қазақстандағы банктік қызметтердің сапасын жақсарту жағдайында банкаралык басекелестік............ 95

Шалдарбеков Қ.Б., Муханова Г.С., Нурмухамбетова 3.С. Аймақтарды дамыту бағдарламаларын жүзеге асырудағы жобалық басқаруды қолданудың шетелдік тәжірибесі

КаратаеваА.М., Бердиярова Ж.С. Мемлекеттік қызметшінің әдептік мәдениеті және құқықтық мәдениеті

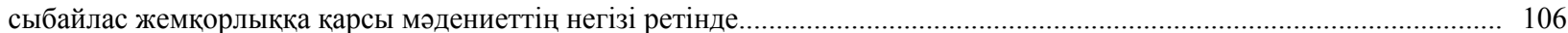

Алдабергенова А.А. Абсурд әдебиетін аударудың лингвомәдени аспектілері ................................................... 113

Стукач В. Ф., Байдалинова А. С., Сандыбаева Б. А. Қазақстанның қаржылық қауіпсіздігі......................................... 119

Баймаханова Д.М., Оспанова Д.А. Конституциялық-құқықтық сана - конституционализмнің маңызды

компоненті ретінде және оның адам құқықтары мәселелерін шешудегі рөлі................................................................. 126

Имангожина 3.А. Сланцевая революция: глобальный тренд на мировом энергетическом рынке............................. 137

Ракаева А.Н., Жуматаева Б.А., Успамбаева М.К., Доскалиева Б.Б. Экологиялық есеп қазақстандағы кәсіпорын экономикасының даму кезеңі ретінде

Нуржанова Г.И. Экономиканың аграрлық секторындағы еңбек әлеуетіне демографиялық фактордың әсері............ 147

Оспанова Д.А., Баймаханова Д.М. Қазақстан Республикасының кибер кеңістігін дамыту жағдайында мемлекеттік қызметтерді цифрландыруда әкімшілік-құқықтық қамтамасыз ету ................................................................................... 152

Pblсnекова М.О., Тлесова Э.Б., Хаитбаева Ф.К. Қазақстандағы тұрғын үй-коммуналдық шаруашылық қызметін

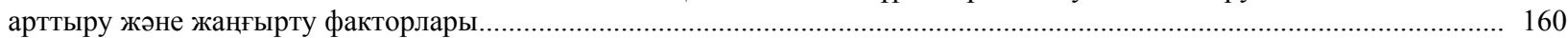

Султанова Г. Т. Аграрлық сектордың экспорттық әлеуетін дамытуға бағытталған үрдістер мен басымдықтар........ 166 


\section{СОДЕРЖАНИЕ}

Алтыбаева С.М., Сагындыков Е.С. Культурный код и мифопоэтическое моделирование в структуре художественного текста

Сембиева Л.М., Мажитов Д.М., Карпиикая М.Е., Хамитова Д.М. Трансформация монетарной системы стран

ЕАЭС в условиях модернизации экономики

Кулсариева А.Т., Султанова М.Э., Шайгозова Ж.Н. Фольклор и идентичность: история, память и мифотворчество

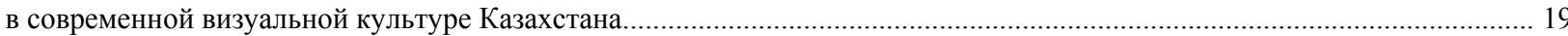

Кенжебаев Д.А. Полигон Сарышаган - краткий исторический анализ................................................................ 26

Абдулина Г.А., БазарбаевА.Г. Современные концепции управления человеческми ресурсами в организациях............ 33

Агыбаев А.Н., Адибаева А.К. Имплементационные механизмы Конвенции ООН о геноциде в уголовных

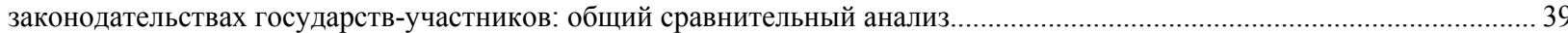

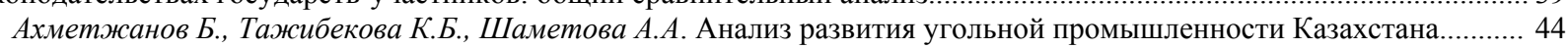

Аюпова 3.К., Кусаинов Д.У.Проблемы конституционно-правового развития республики Казахстан в условиях суверенитета ......

Нурпеисова А.А., Рей И.Ю., Бижанов Д.Т., Тлеужанова Д.А. Основные элементы управления процессом создания инновационной продукции ....

Гиздатов Г.Г. Психолингвистическое исследование концептов казахстанского дискурса......

Ищанова Р.К. Управление государственными расходами - как обеспечение финансовой устойчивости государства. 64

Мадышева А.М. Бикенова А.С., Елеусиз Л.Т. Туристские услуги в сфере образования................................................. 68

Ескалиева А. Ж., Баймуханова М.Т., Ахмурзина Д.О. Перспективы усиления качества человеческого капитала

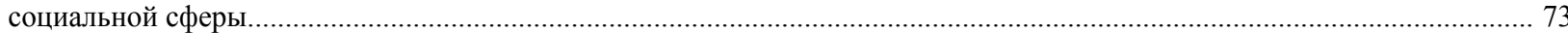

Мархаева Б.А., Козбахова Д.Л. Центр ответственности и трансфертное ценообразование....................................... 79

Сабирова Р.К., Утепкалиева К.М., Кабаков С.Б. Экологические аспекты экономики сельского хозяйства

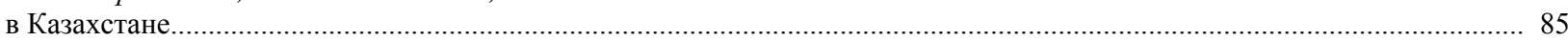

Тлесова Э., Хойч А., Кураш Н. Научно-инновационный потенциал республики Казкастан и его перспективы............ 89

Хамитхан Н. Межбанковская конкуренция в условиях повышения качества банковских услуг в Казахстане..............95

Шалдарбеков К.Б., Муханова Г.С., Нурмухамбетова З.С. Зарубежный опыт применения проектного управления

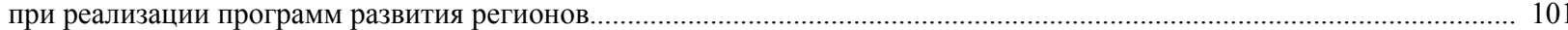

Каратаева А.М., Бердиярова Ж.С. Этическая культура и правовая культура государственных служащих

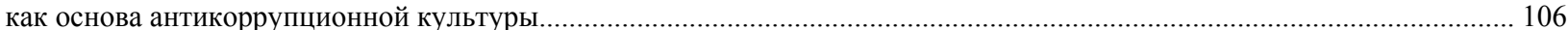

Алдабергенова А.А. Лингвокультурологические аспекты перевода литературы абсурда........................................... 113

Стукач В. Ф., Байдалинова А. С., Сандыбаева Б. А. Казахстанская финансовая безопасность................................... 119

Баймаханова Д.М., Оспанова Д.А. Конституционно-правовое сознание как важный компонент конституционализма

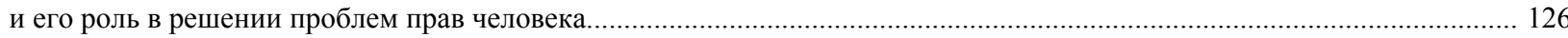

Имангожина 3.А. Сланцевая революция: глобальный тренд на мировом энергетическом рынке............................ 137

Ракаева А.Н., Жуматаева Б.А., Успамбаева М.К., Доскалиева Б.Б. Экологический учет как ступень развития

экономики предприятия в Казахстане............................................................................................

Нуржанова Г.И. Влияние демографического фактора на трудовой потенциал аграрного сектора экономики............ 147

Оспанова Д.А., Баймаханова Д.М. Административно-правовое обеспечение цифровизации государственных услуг в условиях развития кибер пронстранства республики Казахстан......

Рыспекова М.О., Тлесова Э.Б., Хаитбаева Ф.К. Факторы инновационной модернизации и совершенствования деятельности жилищно-коммунального хозяйства в Казахстане

Султанова Г. Т. Тенденции и приоритеты развития экспортного потенциала аграрного сектора... 


\section{CONTENTS}

Altybayeva S.M., Sagyndykov E.S. Cultural code and myth poetic modeling in the structure of the artistic text..................... 5 Sembiyeva L.M., Mazhitov D.M., Karpitskaya M.E., Khamitova D.M. Transformation of the monetary system of the eurasian economic UNION countries in the conditions of modernization of the economy......

Kulsarieva A.T., Sultanova M.E., Shaigozova Zh.N. Folklore and identity: history, memory and myth-making in the modern

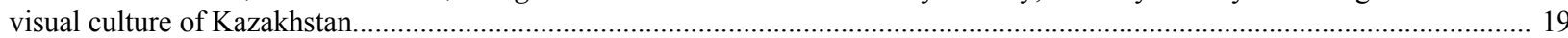

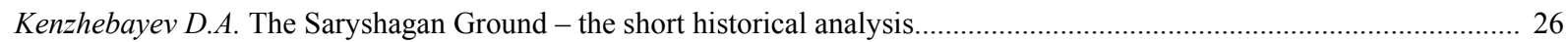

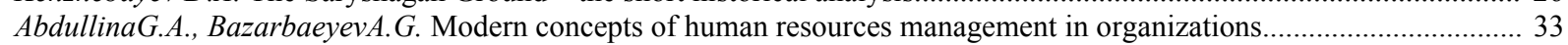

Agybayev A.N., Adibayeva A.K. Implementing mechanisms of the UN Convention on genocide in the criminal legislation

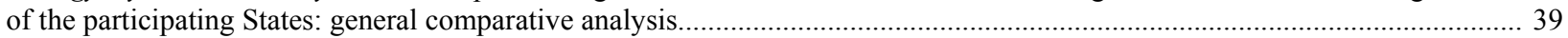

Akhmetzhanov B., Tazhibekova K.B, Shametova A.A. Analysis of development of the coal industry of Kazakhstan.............. 44 Ayupova Z.K., Kussainov D.U. Problems of constitutional and legal development of the republic of kazakhstan in the conditions of sovereignty......

Nurpeisova A.A., Rey I.Yu., Bizhanov D.T., Tleuzhanova D.A. Main elements of managing the process of creating innovation production.

Gizdatov G.G. Psycholinguistic study of the concepts of Kazakhstar

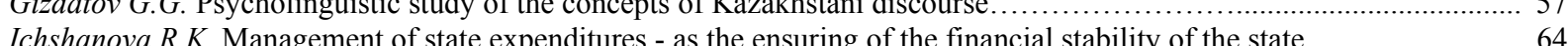

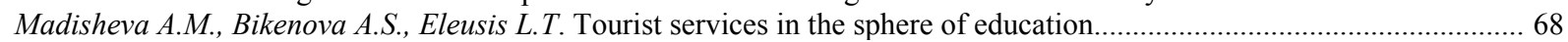

Eskalieva A. Zh., Baymukhanova M.T., Ahmurzina D.O. Perspectives of strengthening the quality of the human capital

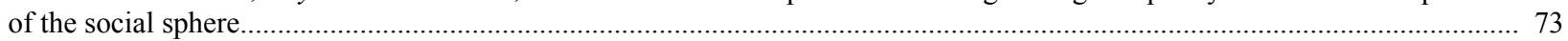

Markhayeva B.A., Kozbakhova D.L. A responsibility center and transfer pricing ................................................. 79

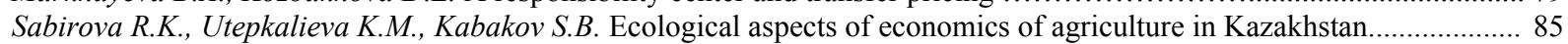

Tlessova E., Khoich A., Kurash N. Scientific innovation potential of the republic of Kazkahstan and its perspectives........ 89

Hamitkhan $N$. Interbank competition in conditions of improving the quality of banking services in Kazakhstan.................. 95

Shaldarbekov K., Mukhanova G., Nurmukhambetova Z. International practices in project management in implementing

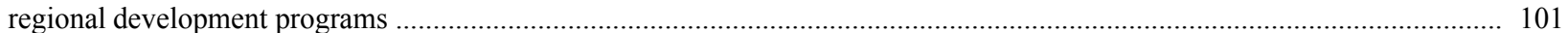

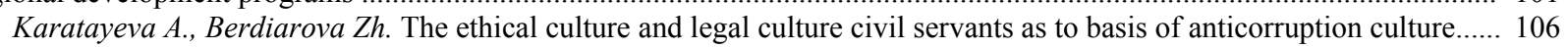

Aldabergenova A.A. Linguocultural aspects of translation of absurd literature.............................................................. 113

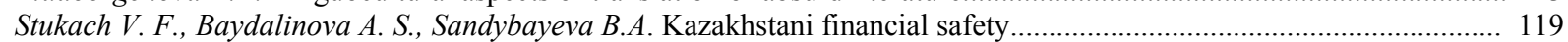

Baimakhanova D.M., Ospanova D.A. Constitutional and legal consciousness as an important component of constitutionalism

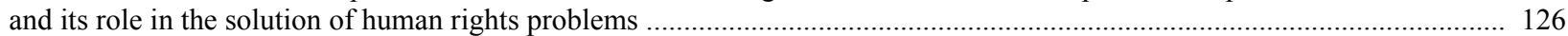

Imangozhina Z.A. Shale gas revolution: global trend in the world energy market..................................................... 137

Rakaeva A.N., Zhumataeva B.A., Uspanbayeva M.K., B.B.Doskalieva. Level of ecological report development in the economic of Kazakhstan's companies.

Nurzhanova G.I. Impact of demographic factors on labor potential of economy's agricultural sector

Ospanova D.A., Baimakhanova D.M. Administrative and legal support of digitalization of public services in the context of the development of cyber space in the republic of Kazakhstan....

Ryspekova M.O., Tlessova E.B., Khaitbayeva F. Factors of innovative modernization and improvement of activity

of housing and communal services in Kazakhstan.

Sultanova G. T. Trends and priorities for the development of export potential of the agrarian sector. 


\title{
PUBLICATION ETHICS AND PUBLICATION MALPRACTICE IN THE JOURNALS OF THE NATIONAL ACADEMY OF SCIENCES OF THE REPUBLIC OF KAZAKHSTAN
}

For information on Ethics in publishing and Ethical guidelines for journal publication see http://www.elsevier.com/publishingethics and http://www.elsevier.com/journal-authors/ethics.

Submission of an article to the National Academy of Sciences of the Republic of Kazakhstan implies that the work described has not been published previously (except in the form of an abstract or as part of a published lecture or academic thesis or as an electronic preprint, see http://www.elsevier.com/postingpolicy), that it is not under consideration for publication elsewhere, that its publication is approved by all authors and tacitly or explicitly by the responsible authorities where the work was carried out, and that, if accepted, it will not be published elsewhere in the same form, in English or in any other language, including electronically without the written consent of the copyrightholder. In particular, translations into English of papers already published in another language are not accepted.

No other forms of scientific misconduct are allowed, such as plagiarism, falsification, fraudulent data, incorrect interpretation of other works, incorrect citations, etc. The National Academy of Sciences of the Republic of Kazakhstan follows the Code of Conduct of the Committee on Publication Ethics (COPE), and follows the COPE Flowcharts for Resolving Cases of Suspected Misconduct (http://publicationethics.org/files/u2/New Code.pdf). To verify originality, your article may be checked by the originality detection service Cross Check http://www.elsevier.com/editors/plagdetect.

The authors are obliged to participate in peer review process and be ready to provide corrections, clarifications, retractions and apologies when needed. All authors of a paper should have significantly contributed to the research.

The reviewers should provide objective judgments and should point out relevant published works which are not yet cited. Reviewed articles should be treated confidentially. The reviewers will be chosen in such a way that there is no conflict of interests with respect to the research, the authors and/or the research funders.

The editors have complete responsibility and authority to reject or accept a paper, and they will only accept a paper when reasonably certain. They will preserve anonymity of reviewers and promote publication of corrections, clarifications, retractions and apologies when needed. The acceptance of a paper automatically implies the copyright transfer to the National Academy of sciences of the Republic of Kazakhstan.

The Editorial Board of the National Academy of sciences of the Republic of Kazakhstan will monitor and safeguard publishing ethics.

Правила оформления статьи для публикации в журнале смотреть на сайте:

$$
\begin{gathered}
\text { www:nauka-nanrk.kz } \\
\text { social-human.kz }
\end{gathered}
$$

\author{
Редакторы М.С. Ахметова, Т.А. Апендиев, Д.С. Аленов \\ Верстка на компьютере А.М. Кульгинбаевой \\ Подписано в печать 10.10.2018 \\ Формат 60x881/8. Бумага офсетная. Печать - ризограф. \\ 11,6 п.л. Тираж 500. Заказ 5.
}

